\title{
Evaluation of Cassava Genotypes for Resistance to Cassava Mosaic Disease and Agronomic Traits
}

\author{
Patrick Chiza Chikoti1 ${ }^{*}$, Paul Shanahan², Rob Melis² \\ ${ }^{1}$ Zambia Agriculture Research Institute, Mount Makulu Research Station, Chilanga, Zambia \\ ${ }^{2}$ University of KwaZulu-Natal, African Center for Crop Improvement, Pietermaritzburg, South Africa

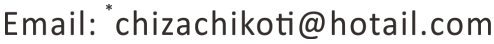

Received 6 February 2016; accepted 17 May 2016; published 20 May 2016

Copyright (C) 2016 by authors and Scientific Research Publishing Inc.

This work is licensed under the Creative Commons Attribution International License (CC BY). http://creativecommons.org/licenses/by/4.0/

(c) (i) Open Access

\begin{abstract}
Sixteen cassava genotypes comprising introductions, local landraces and improved genotypes were evaluated for two seasons in Mansa, Zambia, for their reaction to cassava mosaic disease (CMD). The study was conducted in 2009/10 and 2010/11 seasons to evaluate the reaction of cassava cultivars to CMD and agronomic traits. Cassava mosaic disease severity and leaf retention were scored at 6 months after planting (MAP) and data on yield and yield components were recorded at harvest (7 MAP). Significant genotype $x$ season interaction for CMD, harvest index, fresh root yield, biomass, plant height, root size and leaf retention was recorded. Bangweulu, Kalaba, Chikula, Mwakamoya and Chila-7 were the most susceptible genotypes over the two seasons. Mweru, Kampolombo, TMS190, TMS3001, Tanganyika and Nalumino had low severity scores. Harvest index ranged from 0.36 (Mwakamoya) to 0.55 (Chila-7) for the combined seasons. Chila-7 had the highest fresh root yield with a mean of $0.87 \mathrm{~kg}$ plant ${ }^{-1}$ for the combined seasons. The resistant genotypes might be used to improve the CMD resistance of local cultivars through hybridisation.
\end{abstract}

\section{Keywords}

Cassava, Disease, Yield and Yield Components, Genotype

\section{Introduction}

Cassava forms an integral part of the farming system in Zambia. A number of cassava landraces are grown by

\footnotetext{
${ }^{*}$ Corresponding author.
}

How to cite this paper: Chikoti, P.C., Shanahan, P. and Melis, R. (2016) Evaluation of Cassava Genotypes for Resistance to Cassava Mosaic Disease and Agronomic Traits. American Journal of Plant Sciences, 7, 1122-1128. 
smallholder farmers mainly in Luapula, Northern, North Western, Western and parts of central provinces. In most of the communities, the crop is grown for its storage root. The cassava roots have variable uses such as fresh food, animal feed [1], starch extraction and alcohol production [2]. One of the important breeding objectives in many research institutions, for example the International Institute for Tropical Agriculture (IITA) and Centro Internationcional de Agricultura Tropical (CIAT), is producing cultivars which are high yielding, early bulking, resistant to pests and diseases, and with low cyanide glycoside content (HCN). However, many of the cultivars grown in Zambia are susceptible to pests and diseases.

One of the farmers' primary concerns is having planting materials which are resistant to important diseases, as diseases are the major constraints to cassava production [3]. Without proper management of CMD, the disease may prove difficult to eradicate especially in planting materials perceived to be free from the disease. A practical solution is selecting cultivars that resist CMD infection. Increased resistance to CMD offers hope of achieving higher yields and improving household food security especially in rural communities. Plants are resistant to CMD, partition more carbohydrates to the storage roots which result in improved yields.

Evaluation of local cassava cultivars is necessary in order to generate important information that can form the basis of a breeding programme for CMD resistance in Zambia. The objectives of the study are: to evaluate the reaction of introductions, local and improved cassava cultivars to CMD and agronomic traits.

\section{Materials and Methods}

\subsection{Location and Site Description}

The trial was carried out at Mansa Research Station in 2009/10 and 2010/11 seasons. The trials were established on 10 December of each season. Mansa experiences a monomodal rainfall pattern and receives between 1000 and $1500 \mathrm{~mm}$ of rainfall per year primarily from November to April. The mean annual minimum temperature is $10^{\circ} \mathrm{C}$ and means annual maximum temperature is $31^{\circ} \mathrm{C}$. The soils are acidic at both sites and have been classified as sandy loam, well drained to imperfectly drained [4]. The vegetation of the trial site is predominantly Miomboand interspersed with grass [5].

\subsection{Germplasm}

The germplasm used in the research study was obtained from Mansa Research Station, Mount Makulu Gene Bank, and IITA (Table 1). The local and improved genotypes are widely grown in Zambia especially in Northern, Luapula, North-Western, Western and parts of central provinces. The genotypes were not randomly sampled, therefore they were considered as fixed effects.

\subsection{Experimental Layout and Management}

The design used was a $4 \times 4 \alpha$ lattice with three replications. The experimental field was ploughed with a tractor and ridges made manually using hoes at spaces of $1 \mathrm{~m}$ between the ridges (height of ridges, $40 \mathrm{~cm}$ ). Mature cassava cuttings from plants certified to be disease free measuring $30 \mathrm{~cm}$ in length were planted vertically, $1 \mathrm{~m}$ apart on the ridges. Each cultivar was planted on four ridges per plot. The length of each ridge was $11 \mathrm{~m}$. Weeding was done manually and no fertilizer was applied. The two trials were grown with no supplementary irrigation.

Although Luapula province is considered to be a hot spot for CMD and has a favourable environment (rainfall and high temperatures), the whitefly population is low. Augmented transmission of CMD to the test plants was necessary. Therefore, additional cassava plants exhibiting CMD symptoms were collected from farmers' fields within Luapula province.

The collected diseased plants were planted in the screenhouse. Water was applied regularly and monocrotophos was sprayed to control cassava green mites. Once the plants were ready to be used as source of virus inoculum, grafting was carried out 3 MAP on test plants in the field in 2009/10 and 2010/11 seasons. The scion (diseased plant) was cut to a tapered shape and the root stock (test plant) cut to a wedge shape. With the scion and the root stock in direct contact and held in position, a plastic strip was firmly wrapped around the graft union. In addition to grafting, CMD susceptible local cultivars were planted in each of the first and fourth rows between the test plants as spreaders. 
Table 1. List of cassava cultivars evaluated for agronomic traits.

\begin{tabular}{cccc}
\hline Entry & Cultivar & Local Landrace/Improved & Source \\
\hline 1 & Nalumino & Local landrace & Mansa Research Station \\
2 & Bangweulu & Local landrace & Mansa Research Station \\
3 & Namuyongo & Local landrace & Mansa Research Station \\
4 & Kabala & Local landrace & Mansa Research Station \\
5 & Chikula & Local landrace & Mt. Makulu Gene bank \\
6 & Mwakamoya & Local landrace & Mansa Research Station \\
7 & Chila 7 & Local landrace & Mansa Research Station \\
8 & Manyopola & Local landrace & Mansa Research Station \\
9 & Chila 11 & Local landrace & Mansa Research Station \\
10 & Chila & Improved & Mansa Research Station \\
11 & Tanganyika & Improved & Mansa Research Station \\
12 & Kampolombo & Improved & Mansa Research Station \\
13 & Mweru & Improved & Mansa Research Station \\
14 & TMS190 & Improved & IITA ${ }^{1}$ \\
\hline 16 & Improved & IITA \\
\hline
\end{tabular}

${ }^{1}$ IITA (International Institute of Tropical Agriculture).

\subsection{Data Collection}

Data on CMD severity was collected from the two middle ridges using the 1 - 5 scale [6] where: $1=$ no symptoms observed; 2 = mild chlorotic pattern over entire leaflets or mild distortion at the base of leaflets only, with the remainder of the leaflets appearing green and healthy; 3 = moderate mosaic pattern throughout the leaf, narrowing and distortion of the lower one-third of leaflets; 4 = severe mosaic, distortion of two thirds of the leaflets and general reduction of leaf size; 5 = severe mosaic distortion of the entire leaf; data was collected on a monthly basis for three months after grafting.

\subsubsection{Fresh Root Yield and Harvest Index}

At harvest time (7 MAP), the number and mass ( $\mathrm{kg}$ ) of all the storage roots per plant were counted and recorded. In addition, root size was classed as: size 3 (small sized roots); size 5 (medium sized roots); and size 7 (large sized roots). The fresh root mass and the total fresh biomass for each plant were determined. Harvest index (HI) was calculated as the ratio of fresh root yield to fresh total biomass.

\subsubsection{Leaf Retention}

The cassava clones were visually evaluated for leaf retention at 6 MAP [7]. The trait was quantified on a scale of 1 to 5 , where: 1 = very poor retention; $2=$ less than average retention; $3=$ average leaf retention; $4=$ better than average retention; and $5=$ outstanding leaf retention.

\subsection{Statistical Analysis}

Statistics for all the variables evaluated was carried out using Genstat Version 14 [8]. Analysis of variance (ANOVA) was performed on the two season data. Bartlett's test was also performed on individual seasons. The genotypes were considered as fixed effects, while sites and replications were considered as random effects. Pearson correlation analysis using Genstat procedures was used to determine the relationships among the biotic 
and agronomic traits. The relative contribution of the different traits towards the genotype performance was estimated by principal component analysis (PCA) [9].

\section{Results}

The CMD severity scores ranged from 1 to 4 with a mean of 2.0. Harvest index was as low as 0.07 to as high as 0.79 . Total biomass ranged from 0.1 to $4.1 \mathrm{~kg}^{-1 a n t^{-1}}$. Root size varied from 3 to 5 while fresh root yield ranged from $0.02 \mathrm{~kg}$ plant $^{-1}$ to $2 \mathrm{~kg}_{\text {plant }}{ }^{-1}$.

The chi-square values for all the traits were not significant, indicating that the season error variances were homogeneous. Analysis of variance (ANOVA) revealed significant differences $(\mathrm{P}<0.001)$ among the genotypes across seasons for the biotic and agronomic related traits. The mean squares for the genotypes and genotype $\mathrm{x}$ season interactions were significant $(\mathrm{P}<0.001)$ for $\mathrm{CMD}$, harvest index, total fresh biomass, leaf retention, plant height, root size and fresh root yield.

\subsection{Cassava Mosaic Disease Symptom Expression}

The CMD symptoms appeared three to four weeks after grafting. Appearance of symptoms varied across the genotypes. Mild to severe symptoms of CMD were observed in both seasons on a scale of $1-5$. Observations in the field showed that Bangweulu Kalaba, Chikula, Mwakamoya and Chila-7 were the most susceptible to CMD. Genotypes TME2, TMS190 and TMS3001 expressed mild symptoms, while Chila, Kampolombo, Mweru, and Tanganyika expressed moderate symptoms. The ten most resistant genotypes were TME2, TMS190, TMS3001, Nalumino, Kampolombo, Mweru, Chila, Tanganyika, Manyopola and Chila-11.

\subsection{Cassava Mosaic Disease and Yield Components}

Reaction of the genotypes to CMD differed significantly $(\mathrm{P}<0.001)$. Harvest index varied significantly $(\mathrm{P}<$ 0.001) among the genotypes for the two cropping seasons. Genotype Chila-7 had the highest harvest index (0.55), while Mwakamoya had the lowest (0.36). Bangweulu, one of the popular cultivars had harvest index of 0.45. Leaf retention significantly $(\mathrm{P}<0.001)$ varied with the genotypes. Genotype TMS190 had the highest leaf retention, while Bangweulu, Chikula, Mwakamoya and Tanganyika had the lowest.

\subsection{Agronomic Traits and Yield}

Total fresh biomass varied significantly $(\mathrm{P}<0.001)$ among the genotypes. Chila-7 had the highest $(1.62 \mathrm{~kg}$ plant $\left.^{-1}\right)$ and TMS3001 $\left(0.60 \mathrm{~kg} \mathrm{plant}^{-1}\right)$ the lowest total biomass. There were significant differences $(\mathrm{P}<0.001)$ in plant heights for the genotypes. Chila was the tallest $(92.6 \mathrm{~cm})$ and TMS190 was the shortest $(58.1 \mathrm{~cm})$. Significant $(\mathrm{P}<0.001)$ differences were also observed in root size. Root size ranged from 3.0 (Chikula and Tanganyika) to 4.4 (Kampolombo) with a mean of 3.7. Fresh root yield was significantly $(\mathrm{P}<0.001)$ different. Fresh root yield ranged between $0.24 \mathrm{~kg}$ plant $^{-1}$ (Mwakamoya) to $0.87 \mathrm{~kg} \mathrm{plant}^{-1}$ (Chila-7).

\subsection{Phenotypic Correlation of Cassava Mosaic Disease and Agronomic Traits}

Total fresh biomass was significantly $(\mathrm{P}<0.001)$ and positively correlated to leaf retention, root size, CMD and fresh root yield (Table 2). A positive and significant correlation was also observed between harvest index and fresh root yield, root size. Leaf retention was significantly $(\mathrm{P}<0.01)$ positively correlated to fresh root yield and root size. A weak and negative correlation was observed between leaf retention and CMD. Root size was significantly correlated to fresh root yield. Cassava mosaic disease was significantly positively correlated with plant height, total biomass and fresh root yield.

\subsection{Trait Contribution to Genotype Performance}

The first three principal components (PCs) accounted for $83.5 \%$ of the total variation (Table 3). The PC1 accounted for $44.0 \%$ total variation with an eigenvalue of 2.20 . The major contributors for the first PC were total fresh biomass, root size and fresh root yield. Principal component two and PC3 accounted for $20.5 \%$ and $18.9 \%$ of variability respectively. The major factors for PC2 were total fresh biomass, harvest index, leaf retention and root size. For PC3 the major factors were harvest index, leaf retention and root size. 
Table 2. Phenotypic correlation of 16 genotypes for biotic and agronomic traits 7 MAP at Mansa Research Station, Zambia.

\begin{tabular}{|c|c|c|c|c|c|c|c|}
\hline TB & - & & & & & & \\
\hline $\mathrm{HI}$ & 0.02 & - & & & & & \\
\hline LR & $0.21^{* * *}$ & $0.08 \mathrm{~ns}$ & - & & & & \\
\hline $\mathrm{PH}$ & 0.07 & $0.04 \mathrm{~ns}$ & $-0.15^{* * *}$ & - & & & \\
\hline RS & $0.21^{* * * *}$ & $0.13^{* * *}$ & $0.20^{* * *}$ & $-0.02 \mathrm{~ns}$ & - & & \\
\hline FRY & $0.93^{* * *}$ & $0.29^{* * * *}$ & $0.23^{* * *}$ & $0.05 \mathrm{~ns}$ & $0.26^{* * *}$ & - & \\
\hline \multirow[t]{2}{*}{ CMD } & $0.14^{* * *}$ & $-0.06 \mathrm{~ns}$ & $-0.09^{*}$ & $0.13^{* * *}$ & $0.11^{*}$ & $0.14^{* * *}$ & - \\
\hline & $\mathrm{TB}$ & $\mathrm{HI}$ & LR & $\mathrm{PH}$ & RS & FRY & CMD \\
\hline
\end{tabular}

TB (Total Fresh Biomass, kg plant ${ }^{-1}$ ); HI (Harvest Index); LR (Leaf Retention); PH (Plant Height, cm); RS (Root Size); FRY (Fresh Root Yield, kg plant $^{-1}$ ); ${ }^{*}{ }^{* * *}$ Significantly different from zero at the $\mathrm{P}<0.05, \mathrm{P}<0.001$ probability level (two-tailed test), respectively; ns (non significant).

Table 3. Principal component coefficients of the various traits with loadings of the various yield and yield components.

\begin{tabular}{ccccc}
\hline Trait & PC1 & PC2 & PC3 & PC4 \\
\hline TB & 0.604 & -0.419 & 0.054 & 0.017 \\
HI & 0.213 & 0.698 & 0.624 & -0.197 \\
LR & 0.292 & 0.312 & -0.647 & -0.631 \\
RS & 0.312 & 0.448 & -0.375 & 0.749 \\
FRY & 0.639 & -0.198 & 0.219 & -0.028 \\
Eigenvalue & 2.20 & 1.03 & 0.94 & 0.80 \\
\% Variation & 44.0 & 20.5 & 18.9 & 15.9 \\
\hline
\end{tabular}

PC (Principal Component); TB (Total Fresh Biomass, kg plant ${ }^{-1}$ ); HI (Harvest Index); LR (Leaf Retention); RS (Root Size); FRY (Fresh Root Yield, kg plant $\left.{ }^{-1}\right)$.

\section{Discussion}

Evaluation of the 16 cassava genotypes showed significant differences in reaction to cassava mosaic disease across the two planting seasons. None of the genotypes exhibited complete resistance to CMD; however, 56.3\% of the genotypes were more tolerant. The development of CMD was variable in the two seasons, which resulted in different levels of severity scores. This contributed to the genotype $\mathrm{x}$ season interaction. The significant differences between the genotypes and seasons influenced the reaction of the genotypes to CMD infection. The observation agrees with studies by Akainwale et al. [10].

The significant interaction between genotypes and seasons for all the variables indicated the need for evaluation for more than one season. Harvest index varied significantly, with most of the genotypes having values between $44 \%$ to $55 \%$, which was high according to CIAT classification [11]. Seven genotypes (Chila-7, Chila-11, Chila, Tanganyika, Kampolombo, TMS190 and TMS3001) had a harvest index of 50\% or more which was very high according to the optimum value of $50 \%$ to $60 \%$ for cassava [12]. Harvest index was a highly heritable trait [13] [14] and less affected by the environment. Genotypes with high harvest index were considered to be ideal for cultivar improvement.

For most of the genotypes leaf retention ranged from 1.9 to 2.9 on a scale of $1-5$. Leaf retention was a trait in cassava which had been suggested as a possible means of increasing cassava productivity [7]. The moderate leaf retention among some of the genotypes evaluated indicated the need for improvement. Significant variations were observed for fresh root yield indicating wide genetic differences. Yield had been reported as selection criteria for early bulking [11]. Several genotypes yielded more than $0.4 \mathrm{~kg}_{\text {plant }}{ }^{-1}\left(4 \mathrm{t}^{\mathrm{h}} \mathrm{ha}^{-1}\right)$ at $7 \mathrm{MAP}$, though lower than what had been reported by Kamau [15] in Kenya. Harvesting at this stage allowed identification of genotypes with early bulking characteristic. Root yield depended on several climatic and physical factors (rainfall, temperature, soil characteristics) in addition to genetic factors. The rainfall was higher in the 2010/11 season than in the 2009/10 season. This could have influenced the relatively better performance of root yield in the second season. Though cassava was a drought tolerant crop, during initial growth stages moisture content in the 
soil was important. The low fertility associated with the sandy loam soil, particularly nitrogen, could have also contributed to low yields (data not shown) in the first season. Cassava grew well in less fertile soil, however, a considerable amount of nitrogen was required [16].

The major contributors to the performance of the traits as reflected by the PCs were storage root size, fresh root yield, biomass, leaf retention, and harvest index. Leaf retention, harvest index and fresh root yield were among the traits used by the breeders for selecting cassava genotypes.

Significant positive correlation between leaf retention and fresh root yield was observed. Lenis et al. [7] reported positive relationship between fresh root yield and leaf retention. Fresh root yield correlated positively with all the other traits except for plant height. Positive and weak correlation was observed between CMD and biomass, plant height, and fresh root yield. The genotypes used in the study were fixed and the resistant lines were low yielding, this could have contributed to the positive correlation between CMD and some of the traits. The positive correlation of CMD and yield might have been due to early harvesting of cassava (7 MAP) and low virus titre. The observations agreed with Ssemakula and Dixon [17] who reported significant positive correlation between CMD and yield. On the contrary, studies by Okechukwu and Dixon [18] reported negative correlations between CMD and yield. In all cases, CMD had a weak positive correlation, it suggested that CMD had no effect on the particular traits. In some of the newly infected cassava planting materials the impact of CMD on yield is low compared to later stages of growth [19].

In conclusion, 16 genotypes were screened for CMD resistance using spreaders and the grafting method. The grafting ensured presence and uniform distribution of the virus in the test plants. The study showed that most of the local landraces grown are susceptible while others are tolerant to CMD. This suggests that the susceptible genotypes can be improved while maintaining farmer preferred characteristics through hybridisation. Cultivars that showed low or moderate CMD severity could be considered as sources of resistance. The low root yield suggests improvements needs to be made in the genotypes.

\section{Acknowledgements}

We acknowledge Agriculture Green Revolution in Africa (AGRA) for the financial assistance in carrying out the study. The authors gratefully thank Mr. Mathias Tembo and Ms. Dina Mambwe for data collection.

\section{References}

[1] Chhay, T., Preston, T.R. and Ly, J. (2003) The Use of Ensiled Cassava Leaves in Diets for Growing Pigs. http://www.lrrd.org/lrrd15/7/chha157.htm

[2] Tonukari, N.J. (2004) Cassava and the Future of Starch. Electronic Journal of Biotechnology, 7, 5-8. http://dx.doi.org/10.2225/vol7-issue1-fulltext-9

[3] Theiberge, R.L. (1985) Common African Pests and Diseases of Cassava, Yam, Sweet Potato and Cocoyam. IITA, Ibadan, 108.

[4] MACO (1991) Exploratory Soil Map of Zambia. Soil Survey Section, Zambia Agriculture Research Institute, Ministry of Agriculture and Cooperatives (MACO).

[5] Lawton, R.M. (1978) A Study of the Dynamic Ecology of Zambian Vegetation. Journal of Ecology, 66, 175-198. http://dx.doi.org/10.2307/2259187

[6] Hahn, S.K., Terry, E.R. and Leuschner, K. (1980) Breeding Cassava for Resistance to Cassava Mosaic Disease. Euphytica, 29, 673-683. http://dx.doi.org/10.1007/BF00023215

[7] Lenis, J.I., Calle, F., Jaramillo, G., Perez, J.C., Ceballos, H. and Cock, J.H. (2006) Leaf Retention and Cassava Productivity. Field Crops Research, 95, 126-134. http://dx.doi.org/10.1016/j.fcr.2005.02.007

[8] Payne, R.W., Harding, S.A., Murray, D.A., Soutar, D.M., Baird, D.B., Glaser, A.I., Welham, S.J., Gilmour, A.R., Thompson, R. and Webster, R. (2011) The Guide to Genstat Release 14, Part 2: Statistics. VSN International, Hemel Hempstead.

[9] Jollife, I.T. (2002) Principal Component Analysis. 2nd Edition, Springer-Verlag, New York, Inc., USA.

[10] Akainwale, M.G., Akinyele, B.O., Odiyi, A.C. and Dixon, A.G.O. (2011) Genotype x Environment Interaction and Yield Performance of 43 Improved Cassava (Manihot esculenta Crantz) Genotypes at Three Agro-Climatic Zones in Nigeria. British Biotechnology Journal, 1, 68-84. http://dx.doi.org/10.9734/BBJ/2011/475

[11] Kawano, K.P., Daza, P., Amaya, A., Ríos, M. and Gonçalvez, M.F. (1978) Evaluation of Cassava Germplasm for Productivity. Crop Science, 18, 377-380. http://dx.doi.org/10.2135/cropsci1978.0011183X001800030006x 
[12] Iglesias, C.A., Calle, F., Hershey, C., Jaramillo, G. and Mesa, E. (1994) Sensitivity of Cassava (Manihot esculenta Crantz) Clones to Environmental Changes. Field Crop Research, 36, 213-220. http://dx.doi.org/10.1016/0378-4290(94)90113-9

[13] Kawano, K., Narintaraporn, K., Narintaraporn, P., Sarakarn, S., Limsila, A., Limsila, J., Suparhan, D., Sarawat, V. and Watananonta, W. (1998) Yield Improvement in a Multistage Breeding Programme for Cassava. Crop Science, 38, 325332. http://dx.doi.org/10.2135/cropsci1998.0011183X003800020007x

[14] Kawano, K. (1990) Harvest Index and Evolution of Major Food Crop Cultivars in the Tropics. Euphytica, 46, $195-202$. http://dx.doi.org/10.1007/BF00027218

[15] Kamau, J.W. (2006) Participatory Based Development of Early Bulking Cassava Varieties for the Semi-Arid Areas of Eastern Kenya. University of KwaZulu-Natal, South Africa.

[16] Howeler, R.H. (2002) Cassava: Cassava Mineral Nutrition and Fertilisation Biology. In: Hillocks, R.J., et al., Eds., Biology, Production and Utilisation, CABI Publishing, New York, 115-147. http://dx.doi.org/10.1079/9780851995243.0115

[17] Ssemakula, G. and Dixon, A.G.O. (2007) Genotype x Environment Interaction, Stability and Agronomic Performance of Carotenoid-Rich Cassava Clones. Scientific Research and Essay, 2, 390-399.

[18] Okechukwu, U.R. and Dixon, A.G.O. (2009) Performance of Improved Cassava Genotypes for Early Bulking, Disease Resistance and Culinary Qualities in an Inland Valley Ecosystem. Agronomy Journal, 101, 1258-1265. http://dx.doi.org/10.2134/agronj2008.0077

[19] Muimba, K.A. and Phuti, K. (1987) Relationship of Cassava Mosaic Severity in Planting Material to Mosaic Development, Growth and Yield of Cassava in Zaire. Experimental Agriculture, 23, 221-226. http://dx.doi.org/10.1017/S0014479700017026 